Jurnal Care Vol .5, No.3,Tahun 2017

\title{
KETERKAITAN PENGETAHUAN TENTANG KESEHATAN REPRODUKSI REMAJA DENGAN PERILAKU SEKS PRA NIKAH PADA SISWA-SISWI KELAS XI DI SMA PGRI 1 KABUPATEN MAJALENGKATAHUN 2017
}

\author{
Virgianti Nuraldila ${ }^{1)}$ Diyah Sri Yuhandini ${ }^{2)}$ \\ ${ }^{1,2)}$ Prodi D IV Kebidanan Poltekkes Kemenkes Tasikmalaya \\ e-mail: tiradiyah@yahoo.co.id
}

\begin{abstract}
Adolescence is started physical and physiological changes occur. These changes result in the arousal of sexual attraction towards others. Adolescences' lack of sexual education might affect their behaviors about sex before marriage. According to the report by the Directorate General of Disease Control and Environmental Health, the Ministry of Public Health Number 3 year 2014, there were 4,400 people aged between 15 to 24 years old were HIV positives in 2014. This research to identify the correlation between adolescence's reproduction health knowledge and their pre-marriage sexual behavior at SMA PGRI 1 Majalengka. This is an analytical research using cross sectional approach. 139 students were taken as the participants of the study; they were drawn from the total populations of the students in the school. Analyzed through univariate and bi-variate chi-square statistical method. Findings if Adolescences' reproduction bealth knowledge can be categorized as moderate and they have fair pre-marriage sexual behaviors. Chi-square analysis results p value $=, 001$. There is a significant correlation between the adolescences' reproduction bealth knowledge and their pre-marriage sexual behavior at 11 grade students of SMA PGRI 1 Majalengka. The school needs to coordinate with other government health agencies to provide reproduction health education in a more wellorganized way
\end{abstract}

Keyword: Adolescent reproduction health, knowledge, pre marriage sexual behaviors

\begin{abstract}
ABSTRAK
Masa remaja di awali terjadinya perubahan-perubahan fisik dan perubahan fisiologis. Perubahan ini menyebabkan daya tarik terhadap lawan jenis yang merupakan akibat timbulnya dorongan-dorongan seksual. Pengetahuan yang rendah dapat mempengaruhi sikap remaja dalam bersikap mengenai seks pra nikah. Penelitian ini untuk mengetahui hubungan pengetahuan tentang kesehatan reproduksi remaja dengan perilaku seks pra nikah pada Siswa-Siwi Kelas XI di SMA PGRI 1 Kabupaten Majalengka. Penelitian ini merupakan jenis penelitian analitik dengan pendekatan cross sectional. Populasi adalah siswa-siswi kelas XI SMA PGRI 1 Kabupaten Majalengka dengan jumlah sampel 139 siswa-siswi, diperoleh dengan cara total sampling. Analisis data secara univariat dan bivariat dengan menggunakan chi-square.Hasil diketahui bahwa pengetahuan tentang kesehatan reproduksi remaja sebagian besar dalam kategori baik dan perilaku seks pra nikah sebagian besar dalam kategori ringan. Hasil analisis chi-square menunjukkan hubungan yang bermakna ( $\rho$ value $=0,001)$ yakni adanya hubungan pengetahuan tentang kesehatan reproduksi remaja dengan perilaku seks pra nikah pada Siswa-Siswi Kelas XI di SMA PGRI 1 Kabupaten Majalengka. Diharapkan
\end{abstract}


pihak sekolah dapat berkoordinasi dengan Puskesmas sehingga pendidikan kesehatan khusus dalam kesehatan reproduksi remaja dapat dilaksanakan secara rutin dan terprogram.

Kata Kunci : kesehatan reproduksi remaja, pengetahuan, perilaku seks pra nikah

\section{PENDAHULUAN}

Masa remaja di awali oleh masa pubertas yaitu dimana masa terjadinya perubahanperubahan fisik dan perubahan fisiologis. Perubahan ini menyebabkan daya tarik terhadap lawan jenis yang merupakan akibat timbulnya dorongan-dorongan seksual. (Kusmiran, 2011). Perilaku seksual adalah segala tingkah laku yang didorong oleh hasrat seksual, baik dengan lawan jenisnya maupun dengan sesama jenis (Sarwono, 2012).

Survei Demografi dan Kesehatan Indonesia tahun 2012 menunjukkan bahwa berdasarkan daerah tempat tinggalnya, perilaku seksual pra nikah remaja lebih banyak terjadi di daerah perkotaan dibandingkan di daerah pedesaan (BPS, 2013). Salah satu dampak yang diakibatkan oleh perilaku seksual pra nikah pada remaja adalah infeksi HIV dan AIDS. Berdasarkan hasil dari laporan Ditjen PP\&PL Kemenkes RI (2014) terdapat 3.661 penduduk usia 15-24 tahun di Indonesia yang terinfeksi HIV pada tahun 2012, 5.551 pada tahun 2013 dan 4.400 penduduk pada tahun 2014. Menurut
Kesehatan Reproduksi Remaja (SDKI 2012 KRR), bahwa secara nasional terjadi peningkatan angka remaja yang pernah melakukan hubungan seksual pra nikah dibandingkan dengan data hasil Survei Kesehatan Reproduksi Remaja Indonesia (SKRRI) 2007. Hasil survey SDKI 2012 KRR menunjukan bahwa sekitar 9,3\% atau sekitar 3,7 juta remaja menyatakan pernah melakukan hubungan seksual pra nikah. Sehingga selama periode tahun 2007 sampai 2012 terjadi peningkatan kasus remaja yang pernah melakukan hubungan seksual sebanyak 2,3\%. Berdasar SKRRI tahun 2012, Badan Kependudukan dan Keluarga Berencana Nasional (BKKBN) merilis hampir 30\% remaja sudah melakukan perilaku menjurus ke tindak asusila (persetubuhan). SKRRI 2012 menyimpulkan beberapa temuan terkait perilaku berpacaran remaja yang belum menikah. Sebanyak 29,5\% remaja pria dan 6,2\% remaja wanita pernah meraba atau merangsang pasangannya. Sebanyak 48,1\% remaja lakilaki dan 29,3\% remaja wanita pernah berciuman bibir. Sebanyak 79,6\% remaja pria dan $71,6 \%$ remaja wanita pernah berpegangan tangan dengan 
pasangannya.Hasil Riskesdas, menggambarkan bahwa umur pertama kali berhubungan seksual sebelum menikah laki-laki dan perempuan 10-24 tahun, dengan $38 \%$ perempuan mengatakan hubungan seksual terjadi begitu saja, sedangkan $58 \%$ laki-laki merasa penasaran, sebanyak $13 \%$ remaja putri melakukan seks pranikah karena paksaan. Persentase remaja putri 15-19 tahun yang sudah melahirkan dan hamil anak pertama naik dari $8,5 \%$ dari tahun 2007 menjadi 9,5\% pada tahun 2012. Terdapat 10\% remaja putri 15-19 tahun telah menjadi ibu.

Penyebaran HIV/AIDS di Jawa Barat sangat cepat. Angka kejadian HIV/AIDS di Jawa Barat pada Tahun 2012 sebanyak 2.398 orang. Ketua Harian Komisi Penanggulangan HIV/AIDS di Jawa Barat tidak terlepas dari belum pahamnya masyarakat tentang terjadinya dan pencegahan penularan HIV/AIDS (Depkes, 2011). Pengetahuan yang rendah dapat mempengaruhi sikap remaja dalam bersikap mengenai seks pra nikah, menjadikan remaja mempunyai tindakan seksual yang tidak sehat yang pada akhirnya mendekatkan mereka terhadap risiko terinfeksi berbagai macam penyakit menular seksual, termasuk HIV dan AIDS. (Suwarsi, 2016)

Perkembangan remaja ditandai dengan perkembangan kognitif, perkembangan psikososial, dan perkembangan fisik yang dapat mempengaruhi aktivitas seksual yaitu perilaku seks pra nikah. Tingkat perilaku seks pranikah pada remaja menimbulkan dampak yang negatif, yaitu terjadinya kehamilan diluar nikah (Gemala, 2009). Penelitian yang dilakukan oleh Yuni Anayati (2011) tentang hubungan pengetahuan tentang kesehatan reproduksi dan sikap terhadap seksualitas dengan perilaku seksual pada remaja di SMA Safiatudin Banda Aceh menunjukan bahwa dari 4 responden yang pengetahuan kesehatan reproduksi baik terdapat 4 responden dengan perilaku seksual tidak Berisiko Kehamilan Tidak Diinginkan (KTD), sedangkan dari 31 responden yang pengetahuan kesehatan reproduksinya kurang sebanyak 26 responden $(83,9 \%)$ yang perilaku seksualnya beresiko KTD, dan dari 12 responden yang pengetahuan kesehatan reproduksi cukup terdapat 7 responden (58,3\%), dengan perilaku seksualnya beresiko Kehamilan Tidak Diinginkan (KTD).

Berdasarkan studi pendahuluan pada 10 siswa-siswi di SMA PGRI 1 Majalengka didapatkan data bahwa perilaku seksual yang sering mereka lakukan adalah 
berpacaran, berpegangan tangan, berpelukan hingga mencium lawan jenis.

\section{METODE PENELITIAN}

Penelitian ini adalah penelitian analitik kuantitatif desain cross sectional. Populasi dalam penelitian ini adalah seluruh siswasiswi kelas XI SMA PGRI 1 Kabupaten Majalengka sebanyak 139 siswa-siswi (Data siswa, 2017).Sampel diperoleh dengan teknik total sampling. Instrumen yang digunakan dalam penelitian ini adalah kuesioner yang di adopsi dari Sari (2011) yang telah diuji coba reliabilitas dan validitasnya dengan nilai cronbach's alpha 0,709. Kuesioner tentang Pengetahuan kesehatan reproduksi berisi 34 pertanyaan dimana setiap jawaban benar dari masingmasing pertanyaan diberi nilai 1 jika salah diberi nilai 0. Kuesioner tentang perilaku seks pra nikah berisi 11 pertanyaan dimana pertanyaan no 1-7 merupakan perilaku seks pra nikah ringan dan no 8-11 merupakan perilaku seks pra nikah berat.Analisa data menggunakan perangkat lunak SPSS Versi 18.0 dengan uji chi-square $\left(\mathrm{X}^{2}\right)$.

\section{HASIL}

\section{Analisis Univariat}

Berdasarkan Tabel 1 dapat diketahui bahwa sebagian besar siswa-siswi berpengetahuan baik yaitu sebanyak 112 siswa-siswi $(80,6 \%)$.

Tabel 1. Distribusi Frekuensi Gambaran Pengetahuan tentang Kesehatan Reproduksi Remaja pada SiswaSiswi Kelas XI di SMA PGRI 1 Kabupaten Majalengka Tahun 2017

\begin{tabular}{lcc}
\hline Pengetahuan & Jumlah & $\%$ \\
\hline Kurang & 3 & 2,2 \\
Cukup & 24 & 17,3 \\
Baik & 112 & 80,6 \\
\hline Total & 139 & 100 \\
\hline
\end{tabular}

Tabel 2. Distribusi Frekuensi Gambaran Perilaku Seks Pra Nikah Pada Siswa-Siswi Kelas XI di SMA PGRI 1 Kabupaten Majalengka Tahun 2017

\begin{tabular}{lcc}
\hline Perilaku & Jumlah & $\%$ \\
\hline Berat & 34 & 24,5 \\
Ringan & 105 & 75,5 \\
\hline Total & 139 & 100 \\
\hline
\end{tabular}

Berdasarkan Tabel 2 dapat diketahui bahwa sebagian besar siswa siswi memiliki perilaku seks pra nikah dalam kategori ringan yaitu sebanyak 105 siswa-siswi $(75,5 \%)$.

Berdasarkan Tabel 3 hasil uji Chi Square diperoleh nilai $\rho$ value 0,001 , yang berarti ada hubungan antara pengetahuan tentang kesehatan reproduksi remaja dengan perilaku seks pra nikah pada siswa-siswi kelas XI di SMA PGRI 1 Kabupaten Majalengka Tahun 2017. 
Tabel 3. Hubungan antara Pengetahuan Tentang Kesehatan Reproduksi Remaja dengan Perilaku Seks Pra Nikah pada Siswa-Siswi Kelas XI di SMA PGRI 1 Kabupaten Majalengka Tahun 2017

\begin{tabular}{|c|c|c|c|c|c|c|c|}
\hline \multirow{3}{*}{ Pengetahuan } & \multicolumn{4}{|c|}{ Perilaku } & & & \\
\hline & \multicolumn{2}{|c|}{ Berat } & \multicolumn{2}{|c|}{ Ringan } & \multicolumn{2}{|c|}{ Total } & \multirow{2}{*}{$\begin{array}{c}\mathrm{P} \\
\text { value }\end{array}$} \\
\hline & $\mathrm{F}$ & $\%$ & $\mathrm{~F}$ & $\%$ & $\mathrm{~F}$ & $\%$ & \\
\hline Baik & 20 & 17,9 & 92 & 82,1 & 112 & 100 & \multirow{4}{*}{0,001} \\
\hline Cukup & 13 & 54,2 & 11 & 45,8 & 24 & 100 & \\
\hline Kurang & 1 & 33,3 & 2 & 66,7 & 3 & 100 & \\
\hline Total & 34 & 24,5 & 105 & 75,5 & 139 & 100 & \\
\hline
\end{tabular}

\section{PEMBAHASAN}

\section{Gambaran Pengetahuan tentang}

Kesehatan Reproduksi Remaja pada Siswa-Siswi Kelas XI di SMA PGRI 1 Kabupaten Majalengka Tahun 2017

Berdasarkan Tabel 1 diketahui bahwa sebagian besar remaja berpengetahuan baik. Pengetahuan adalah hasil penginderaan manusia atau hasil tahu seseorang terhadap objek melalui indra yang dimilikinya (mata, hidung dan sebagainya), dengan sendirinya pada waktu penginderaan sehingga menghasilkan pengetahuan. Hal tersebut sangat dipengaruhi oleh intensitas perhatian dan persepsi terhadap objek (Notoatmodjo, 2007).Pengetahuan atau kognitif merupakan domain yang sangat penting untuk terbentuknya tindakan seseorang (overt behavior). Karena dari pengalaman dan penelitian ternyata perilaku yang didasari oleh pengetahuan akan lebih langgeng dibandingkan dengan perilaku yang tidak didasari oleh
pengetahuan.Pengetahuan yang diperoleh remaja di dapat dari berbagai sumber salah satunya internet. Menurut Syafrudin, informasi kesehatan reproduksi berasal dari internet. Internet merupakan media yang menyediakan informasi secara bebas tanpa batas walaupun informasi ada yang positif dan negatif (Syafrudin, 2008). Dampak negatif menurut Zakiah bahwa banyak situs-situs internet yang mengungkap secara fulgar (bebas) kehidupan seks atau gambar-gambar yang tidak sesuai untuk remaja yang dapat memberikan dampak kurang baik bagi mereka karena pada saat usia remaja terjadi perubahan psikologis yang mengakibatkan perubahan sikap dan tingkah laku seperti mulai memperhatikan penampilan diri, mulai tertarik dengan lawan jenis, berusaha menarik perhatian dan muncul perasaan cinta yang kemudian akan timbul dorongan seksual. Pada masa remaja cenderung memiliki tingkat seksual yang tinggi sehubungan dengan mulai 
matangnya hormon seksual dan organorgan reproduksi (Fadhila, 2008).

\section{Gambaran Perilaku Seks Pra Nikah pada Siswa-Siswi Kelas XI di SMA PGRI 1 Kabupaten Majalengka Tahun 2017}

Berdasarkan Tabel 2 dapat diketahui bahwa sebagian besar responden mempunyai perilaku seks par nikah dengan kategori ringan. Perilaku seksual pra nikah adalah kegiatan seksual yang melibatkan dua orang yang saling menyukai atau saling mencintai, yang dilakukan sebelum perkawinan. Perilaku seks sebelum nikah memberikan dampak yang buruk bagi remaja. Menurut Syamsulhuda (2010) bahwa dari beberapa perilaku seksual yang termasuk perilaku seksual berisiko berat adalah berciuman bibir, meraba alat kelamin pasangan, menggesek-gesek kelamin sampai dengan hubungan seks. Dampak yang terjadi adalah kehamilan yang tidak diinginkan dan belum siap secara fisik, mental dan sosial ekonomi sehingga calon ibu merasa tidak ingin dan tidak siap untuk hamil, sulit mengharapkan adanya kasih sayang yang tulus dan kuat, sehingga masa depan anak bisa terlantar dan cenderung mengakhiri kehamilannya dengan cara aborsi (Syamsulhuda, 2010).
Berdasar Tabel 2 sebagian remaja melakukan perilaku seks pra nikah dalam kategori berat. Perilaku seksual pra nikah beresiko berat yang sering dilakukan oleh remaja pada saat pacaran yaitu meraba dada pasangan. Hasil penelitian ini menggambarkan bahwa masih banyak perilaku remaja yang menyimpang. Sesuai dengan penelitian Karminingsih (2009) dalam Suara, M (2011) dilaporkan bahwa perilaku seksual remaja SMA dikota Bekasi sebagian besar dalam batas ringan (54,5\%) dan sebesar 45,4\% berperilaku seksual dengan kategori berat. Demikian pula penelitian Sekarini (2011) sebanyak 39,3\% murid SMK Kesehatan daerah Kabupaten Bogor Tahun 2011 berperilaku seksual dalam kategori ringan seperti mengobrol, menonton film berdua, jalan berdua, berpegangan tangan dan berpelukan. Sedangkan sebanyak 60,7\% berperilaku seksual berisiko berat seperti berciuman bibir, mencium leher, meraba daerah erogen, bersentuhan alat kelamin dan melakukan hubungan seks. Dari beberapa hasil penelitian membuktikan bahwa masih banyaknya perilaku seks menyimpang yang dilakukan remaja, terlebih remaja yang telah memiliki pasangan.

Perilaku seks pra nikah pada remaja dapat dipengaruhi oleh beberapa faktor yaitu 
keharmonisan keluarga, sosial, dan media masa. Hawari dalam Afiah (2007) menyatakan bahwa kondisi keharmonisan keluarga dapat membantu terbentuknya sikap negatif pada remaja terhadap seks pranikah. Kurangnya komunikasi secara terbuka antara orang tua dengan remaja dalam masalah seksual dapat memperkuat munculnya perilaku seksual. Adanya perhatian atau kontrol orang tua terhadap anak dapat menunda usia pertama kali remaja melakukan hubungan seks (Widyastuti, 2009).

Perhatian orang tua kepada remaja dapat dilakukan melalui pendekatan psikologis. Kurangnya perhatian menyebabkan munculnya image negatif yang sebenarnya tidak cocok jika dilekatkan ke dalam sosok remaja, pada akhirnya akan menjadi kepribadian di setiap remaja yang ada saat ini. Sebenarnya kasus-kasus diatas itu mempunyai satu titik temu pada masalah kepribadian remaja, yaitu pencarian identitas diri. Bapak Psikologi Remaja, Stanley Hall mengatakan bahwa remaja adalah waktu dimana masa badai dan tekanan psikologi seorang manusia. Semua orang tentu pernah merasakan hal itu. Mungkin diantara kita ada yang benarbenar mengalami jatuh cinta yang memang itu diyakininya bukanlah cinta monyet. Dan saat-saat itulah seolah cinta itu benar- benar indah di matanya. Kita bisa bandingkan cinta seorang anak dengan cinta seorang remaja. Itu hanya sebagian karakteristik psikologi remaja (Walgito, 2003).Dari karakteristik seorang remaja yang telah dituliskan oleh Gunarsa, jika perkembangan remaja tidak baik, maka remaja akan mengalami degradasi moral misalnya adanya keinginan bebas untuk melakukan hal yang dipengaruhi oleh orang lain, aktualisasi diri, dan sikap dan cara berfikir yang kritis yang dipengaruhi lingkungan sekitar. Karena masa remaja adalah masa saat terjadinya perubahanperubahan yang cepat, termasuk perubahan fundamental dalam aspek kognitif, emosi, dan sosial (Fagan, 2006).

Salah satu usaha dalam mengurangi perilaku seks menyimpang yang dapat dilakukan orang tua yaitu melarang anaknya untuk melakukan pacaran. Melarang anak pacaran dapat mencegah anak untuk berperilaku seks pranikah berat seperti meraba-raba bagian dada atau kelamin; membatasi tontonan yang kurang mendidik, mengawasi penggunaan media informasi seperti internet serta membekali anak dengan pendidikan Agama yang baik dan kuat. Pentingnya mengubah image orang tua bahwa sekolah-sekolah yang berlatar pendidikan agama itu terbelakang, 
kampungan dan tidak memiliki masa depan yang bagus untuk anak.

\section{Hubungan Antara Pengetahuan Tentang Kesehatan Reproduksi Remaja Dengan Perilaku Seks Pra Nikah}

Ada hubungan antara pengetahuan tentang kesehatan reproduksi remaja dengan perilaku seks pra nikah pada siswasiswi kelas XI di SMA PGRI 1 Kabupaten Majalengka Tahun 2017. Hasil penelitian ini sejalan dengan hasil penelitian yang dilakukan oleh Dewi Rosalia Amalia (2015), didapat hasil ada hubungan tentang kesehatan reproduksi remaja terhadap perilaku pacaran pada remaja putri di SMK Farmasi Wiyata Farma Kecamatan Kertosono Kabupaten Nganjuk. Peneliti berpendapat bahwa perilaku tumbuh diawali dari pengetahuan yang dipersepsikan sebagai suatu hal yang baik (positif) maupun yang tidak baik (negatif). Dari apa yang diketahui tersebut akan berpengaruh pada perilakunya. Jika yang dipersepsikan tersebut bersifat positif, maka seseorang cenderung berperilaku positif sesuai dengan persepsinya, begitu sebaliknya. Tetapi seringkali dalam kehidupan realitasnya, ada banyak faktor lain yang mempengaruhi seseorang, tidak hanya perilaku dan pengetahuan seseorang, melainkan bisa juga lingkungan sosial, situasi atau kesempatan.

Hasil wawancara dengan Guru Bimbingan Konseling(BK), disampaikan bahwa SMA ini pernah berkoordinasi dengan Puskesmas dalam kesehatan reproduksi pada tahun 2015, tetapi hanya dilakukan pada tahun itu saja karena tidak berkoordinasi lagi di tahun berikutnya tanpa ada sebab. Jika ada siswa-siswi yang melakukan penyimpangan seksual hingga melakukan perilaku seksual maka pihak sekolah hanya mencari solusi untuk meyelesaikan permasalahannya dengan orang tua, tetapi jika siswi tersebut sudah terjadi kehamilan diluar nikah maka pihak sekolah memberikan sanksi yaitu dikeluarkan dari sekolahnya.Namun demikian, Guru BK selalu memberikan bimbingan dan konseling kepada setiap siswa-siswi sesuai dengan jadwal yang telah ditentukan, jika terdapat masalah yang terjadi pada siswa-siswi, maka pada saat itu juga disampaikan pada siswasiswinya, tetapi seringkali mereka tidak memahaminya dengan baik dan tidak diaplikasikan sesuai dengan harapan guru BK. Usia siswa siswi relatif masih sangat muda, sehingga di usia mereka rasa penasaran yang tinggi untuk mencoba dalam hal baru serta banyaknya faktor lingkungan yang dapat mempengaruhi 
misalnya dipengaruhi oleh teman dekat. Pada saat remaja, teman dianggap orang yang paling penting dibandingkan orang tua, karena pada usia remaja biasanya cenderung ingin membuktikan diri dan tidak bergantung lagi pada orang tua. Biasanya pada usia remaja lebih merasa nyaman jika bersama teman-temannya maka tak heran bila remaja mempunyai kecenderungan untuk mengadopsi informasi yang diterima oleh temantemannya. Dengan demikian mereka berani mencoba untuk melakukan mulai dari hal yan ringan hingga berat misalnya berperilaku pacaran, berciuman hingga melakukan hubungan seks pra nikah.

Seseorang melakukan tindakan karena adanya pengetahuan dan sikap yang dimilikinya. Maka dalam hal ini sangat penting sekali pengetahuan tentang reproduksi untuk remaja. Sesuai dengan Notoatmodjo(2007) bahwa tindakan yang dilandasi pengetahuan akan lebih langgeng dibandingkan dengan tindakan yang tanpa pengetahuan yang baik tentang kesehatan reproduksi maka diharapkan remaja dapat mengontrol perilaku seksualnya (Notoatmodjo, 2007).Perilaku seks pra nikah remaja dipengaruhi pula oleh faktor lingkugan. Sprecher dalam Rimawati (2010) menyatakan faktor yang berhubungan dengan standar kebebasan seks pra nikah adalah kerentanan dari jenis tempat tinggal seperti asrama/kostkosant. Remaja yang baru memasuki dunia perkuliahan memiliki keinginan untuk hidup mandiri dan jauh dari orang tua. Salah satu caranya adalah dengan tinggal di asrama atau kost-kostan. Asrama atau kostkostan, kebebasan dalam melakukan sesuatu yang mereka senangi serta kurangnya pengawasan dari pemilik kost atau kontrol dari orang tua dapat membuat remaja memiliki keinginan untuk mencoba hal baru. Apabila remaja mendapatkan pengaruh negatif dari luar dan tidak memiliki pertahanan diri yang kuat dapat terjerumus ke dalam perilaku seksual pranikah.

Demikian pula informasi seksual juga berperan perilaku seksual remaja. Menurut Yulita Amaliyasari (2016) informasi seksual ternyata mempunyai pengaruh terhadap perilaku seksual responden. Responden yang mempunyai pengalaman pernah mendapat informasi tentang seks yang tidak benar lebih banyak melakukan perilaku seks bebas daripada yang tidak pernah mendapat informasi tentang seks. Hal ini disebabkan karena seiring dengan perubahan/inovasi teknologi dan komunikasi global, terjadi perkembangan perilaku reproduksi atau perilaku seks remaja (Laksmiwati, 2008). Semakin tinggi 
intensitas remaja dalam mengakses situs seks, semakin tinggi pula permisivitas perilaku seksualnya. Menurut Jufri dalam Pustaka Latansa (2007), faktor yang paling berpengaruh terhadap perilaku seksual yaitu sering menonton VCD porno, membaca bacaan porno, dan sebagainya. Sumber informasi seksual paling banyak yang sering digunakan oleh responden yaitu lebih dari satu macam media. Bisa media elektronik, media cetak, maupun secara langsung (tanpa media). Begitu mudahnya media yang menonjolkan seks diakses oleh siapa saja membuat peluang responden untuk berperilaku seksual tidak wajar lebih besar dibandingkan respoden yang tidak pernah mendapat informasi tentang seks yang tidak benar.

Peneliti berpendapat walaupun sebagian besar siswa-siswi memiliki pengetahuan baik dalam kesehatan reproduksi remaja namun memiliki perilaku seks pra nikah dalam kategori ringan. Banyaknya siswasiswi yang melakukan perilaku seks pra nikah dalam kategori ringan disebabkan beberapa faktor diantaranya yaitu faktor sosial, keluarga, lingkungan, teman sebaya, dan media masa.Beberapa faktor tersebut sangat berpengaruh terhadap siswa-siswi tersebut. Misalnya pengaruh teman sebaya, karena pada usia siswa-siswi tersebut sangat rentan untuk dapat dipengaruhi oleh temannya. Jika mereka bergaul dan dapat memilih teman yang baik maka akan berdampak baik pula terhadap perilakunya, begitu sebaliknya jika dia tidak dapat memilih teman yang baik maka akan berpengaruh terhadap perilakunya dan mengikuti seperti temannya yang dilakukan. Begitupun dengan media masa yang sangat mudah diakses oleh semua orang, misalnya internet yang dapat dengan mudah untuk mengakses bebas misalnya mengakses video porno, dengan rasa penasarannya maka dapat melihat video tersebut kemudian melakukan untuk berperilaku seperti apa yang mereka tonton.Lingkungan sendiri yang berfungsi sebagai kontrol mempengaruhi antara pengetahuan terhadap kejadian perilaku seksual. Jika seseorang dalam merespon lingkungan tetap berpegang teguh pada tuntutan agama dan taat kepada Tuhan, maka akan mengarahkan tingkah lakunya ke arah kebaikan dirinya. Sebalikya jika dalam merespon lingkungan itu akan mengikuti dorongan syahwat dan pikiran rendahnya, maka sisws-siswi akan terbawa kepada tingkah laku yang mencelakakan dirinya.

Untuk mencegah agar perilaku seks pra nikah pada remaja tidak masuk dalam kategori yang menyimpang, pihak sekolah 
dapat menambahkan muatan lokal tentang pelajaran kesehatan reproduksi remaja atau mengadakan kegiatan keagaamaan dengan diadakannya pengajian secara rutin setiap 2 minggu sekali dengan jadwal yang telah ditentukan sehingga siswa-siswi tersebut dapat mengisi waktunya dalam kegiatan yang positif dan terhindar dari perilaku seks pra nikah.Diharapkan orang tua dapat memantau anaknya tidak ada kegiatan di sekolah maka orang tua dapat mengikutsertakan dalam kegiatan-kegiatan yang positif seperti mengikuti kegiatan ekstrakulikuler dalam bidang olahraga, seni maupun bahasa, serta dapat juga mengikuti organisasi baik OSIS, Pramuka, PMR dan lain sebagainya.

\section{KESIMPULAN}

1. Pengetahuan tentang kesehatan reproduksi remaja pada siswa-siswi kelas XI di SMA PGRI 1 Kabupaten Majalengka sebagian besar yang berpengetahuan baik.

2. Perilaku seks pra nikah pada siswasiswi kelas XI di SMA PGRI 1 Kabupaten Majalengka dalam kategori ringan

3. Terdapat hubungan yang signifikan antara pengetahuan tentang kesehatan reproduksi remaja dengan perilaku seks pra nikah pada siswa-siswi kelas
XI di SMA PGRI 1 Kabupaten Majalengka kelas XI Tahun 2017.

Direkomendasikan bahwa penelitian ini dapat dijadikan pertimbangan untuk memasukkan kurikulum muatan lokal kesehatan reproduksi yang diberikan kepada siswa-siswi, memberikan bimbingan konseling yang lebih intensif dan mendalam, melakukan koordinasi dengan instansi-instansi terkait supaya para siswa-siswi mendapatkan materi tentang KRR serta melakukan koordinasi melalui pertemuan dengan orang tua yang bertujuan agar kegiatan yang dilakukan oleh siswa-siswi dapat diawasi dengan baik.

\section{REFERENSI}

Apriani, A. (2010) Hubungan Antara Pengetahuan tentang Risiko Kehamilan Remaja di Luar nikah dengan Sikap Terbadap Hubungan Seksual Pranikah Pada Siswa SMAN 2 Magetan. Surakarta: Universitas Sebelas Maret.

Fagan. (2006). Psikologi Remaja. PT Gramedia. Jakarta

Fadhila, Hasna.(2008).Perilaku Siswa dalam Pengakses Situs Porno melalui Internet terbadap Rangsangan Seksual di SMK Swasta Raksana Medan Tabun 2008. 
Sumatera: Universitas Sumatera Utara.

Laksmiwati.(2008).Sosial dan Perilaku Reproduksi Remaja. Avaible : www.ejournal.unud.ac.id [Accessed 30 Mei 2017]

Notoatmodjo.(2003).Pendidikan dan Perilaku Kesehatan, Jakarta:Rineka Cipta.

Sari, A.A.S. (2011). Hubungan antara tingkat pengetahuan tentang kesehatan reproduksi dan akses internet khusus situs porno dengan perilaku seksual remaja. Karya Tulis Ilmiah. DIV Kebidanan Poltekkes Kemenkes Tasikmalaya. Sarwono.(2003). Pendidikan dan Perilaku Seksual Pranikah. Edisi

$$
\begin{aligned}
& \text { Revisi,Jakarta : Penerbit } \\
& \text { Grafindo Jakarta. }
\end{aligned}
$$

Syamsulhuda.(2010). Faktor yang Mempengarubi Seks Pranikah Mahasiswa di Pekalongan Tabun 2010. Pekalongan: Universitas Diponegoro

Syafrudin.(2008). Remaja dan Hubungan Seksual Pranikah. Avaible : http://remaja-dan-hubungansekssual-pranikah [Accessed 29 Mei 2017]

Walgito.(2003).Psikologi Sosial (Suatu Pengantar), Yogyakarta. Media Abadi

Widyastuti.(2009). Kesehatan Reproduksi. Yogyakarta. Fitramaya 